\title{
Пути морфологических преобразований жизненных форм у представителей рода Androsace L.
}

\section{Ways of morphological transformations of life forms in representatives of the genus Androsace $\mathrm{L}$.}

\author{
Любезнова Н. В. \\ Lyubeznova N. V. \\ Московский государственный университет имени М. В. Ломоносова, г. Москва, Россия. E-mail: nvlubeznova@gmail.com \\ Lomonosov's Moscow State University, Moscow, Russia
}

Peфераm. В нашей работе были исследованы растения рода Androsace L. разных жизненных форм: однолетние, озимые, двулетние, многолетние дерновинные и растения- подушки. Была изучена схема ветвления всех жизненных форм. Изначальной была признана жизненная форма двулетнего растения. Построены возможные схемы преобразования от исходной жизненной формы двулетника через озимую к однолетнику и через многолетнюю дерновинную жизненную форму к растению- подушке.

Ключевые слова. Двулетники, жизненные формы, морфологические преобразования, растения-подушки Androsace.

Summary. In our work, we investigated plants of the genus Androsace L. of different life forms: annual, winter crops, biennial, perennial, and cushion plants. The branch pattern has been studied in all life forms. The ancestor life form was the form of a biennial plant. Possible transformation schemes from the ancestral form through the winter crops to the annual and through the perennial to the plant cushion are constructed.

Key words. Androsace, biennials, life forms, morphological transformations, plant cushion.

Расселяясь и приспосабливаясь к новым местам обитания, растения часто изменяют свою морфологическую и анатомическую структуру. Переход от многолетней к однолетней жизненной форме встречается чаще, обратная трансформация бывает очень редко, так как у однолетников обычно утрачена многолетняя работа камбия. Наша работа по изучению морфологии и анатомии многолетних дерновинных видов Androsace L. показала, что эти виды происходили от малолетних предков (Любезнова, 2017). У многолетних видов отсутствовало утолщение многолетних осевых органов. Исследовав наиболее распространенные малолетние особи, мы составили схему наиболее вероятных морфологических преобразований в роде Androsace.

Результаты секвенирования ITS последовательностей пластидного генома показали, что род $A n$ drosace в широком смысле является монофилетической группой (Schneeweiss et al., 2004; Boucher et al., 2012), а разделение на несколько родов являлось неправильным. Монофилетический род распадается на две большие клады, одна распространена в Европе, северо-востоке Азии и северо-западе Америки, другая - в Центральной Азии, включая Тибет (Boucher et al., 2012; Roquet et al., 2013). C. Roquet et al. (2013) считают, что предки современных Androsace сначала расселились в Европу, а потом по северу Азии в Америку. Логичнее из полученных данных считать, что по Евразии виды Androsace расселялись двумя волнами. Первая волна, давшая начало европейско-американской кладе, начала распространяться в раннем миоцене, в среднем дошла до Европы, в позднем - до Америки. Последующее оледенение вызвало дизъюнкцию ареала, а также образование новых видов. После последнего оледенения последовала вторая волна распространения видов, уже принадлежащих к азиатской кладе (Roquet et al., 
2013). Интересно, что у всех авторов (Boucher et al., 2012; Roquet et al., 2013) получилось, что в основании древа находятся малолетники, а дерновинные и жизненные формы подушки произошли от них при освоении высокогорных и арктических областей. Также исследования показали, что морфологические и анатомические признаки недостаточны для составления адекватной классификации рода, и нередко в один вид объединяют похожих представителей и евро-американской, и азиатской клады. Как в Androsace lechmaniana Spreng. объединяют растения с Кавказа, Средней Азии, Саян и Androsace triflora Adams, который входит в евро-американскую кладу и очень близок к виду Douglasia ochotensis (Willd. ex Roem. et Schult.) Hult.

Androsace capitata Willd. ex Roem. et Schult. был собран нами у подножия Ключевской сопки на гераниево-копеечниковых лугах (Hedysarum hedysaroides (L.) Schinz. et Thell. - Geranium erianthum DC.), и на склоне гребня рядом с зарослями карликовой ивы-Salix tschuktschorum A. Skvorts. в 2013 г. Androsace villosa L. был собран в 2009 г. на каменистых выступах на южном склоне по борту перевала Аишхо (верховья реки Пслух), на границе альпийского и субальпийских поясов (около 1800 м над ур. моря). Androsace albana Stev. - в 2004 и 2005 гг. на альпийских лишайниковых пустошах, расположенных на южном склоне г. Малая Хатипара в Тебердинском заповеднике на высоте 2800 м над ур. м. Androsace septentrionales L. - в конце мая в 2016 г. на базе отдыха "Чемальская лагуна" по правому берегу р. Катунь. Androsace maxima L. - в конце мая в 2016 г. по правому берегу р. Катунь на 5 км выше с. Чемал, и в 2018 г. в окрестностях п. Первомайский, западный Алтай. Androsace lactiflora Pall. - в конце мая в 2018 г. в окрестностях п. Первомайский, западный Алтай. Androsace filiformis Retz. - в Подмосковье в 2007 г. Был просмотрен гербарий Московского университета для статистической проверки построенных схем, а также еще виды Androsace elongata L., Douglasia arctica Hook. Douglasia ochotensis (Willd. ex Roem. et Schult.) Hult.

Собранный материал был зафиксирован в смеси спирта, глицерина и воды в пропорции $(1: 1: 1)$. Морфологическую и анатомическую структуру растений изучали с помощью бинокулярной лупы МБС - 1 и микроскопа Биолам-70 и Axiopian 2 imaging с программой Axoivision 15.0. Для выявления лигнина использовали реакцию флороглюцина с концентрированной соляной кислотой.

Первые Androsace, по-видимому, были двулетниками, но сначала мы рассмотрим схему ветвления однолетних форм, так как она является простой частью схемы ветвления у двулетников (рис. 2a-c). У всех исследованных озимых и однолетних форм существует одинаковый тип ветвления. В виргинильном периоде формируется розетка листьев разной величины в зависимости от вида и благоприятности условий в месте произрастания данной особи. При сильном апикальном доминировании вегетативная розетка не ветвится, и в пазухах листьев почки не образуются. При переходе в генеративное возрастное состояние апикальная меристема начинает формировать соцветие (рис. 1a), и апикальное доминирование снимается. Для всех видов Androsace характерно супротивное листорасположение. В пазухах листьев начинают формироваться почки с пазушными соцветиями. Наиболее развитые почки в пазухах верхней пары листьев, у второй пары развиваются реже. Почки остальных розеточных листьев подавляются. Пазушное соцветие II порядка имеет розетку из двух листьев и соцветие (рис. 1в). В благоприятных условиях ветвление продолжается, и новые соцветия III порядка формируются в пазушных листьях боковых соцветий II порядка и образуют розетку из пары листьев и соцветие III порядка (рис. 1c). Подобный тип ветвления характерен для Androsace elongata, Androsace filiformis, Androsace maxima и Androsace septentrionales. В экстремальных условиях, например, у особи Androsace maxima, у которой были съедены пасущимися животными апикальное и боковые соцветия двух верхних пар листьев, наблюдалось раскрытие почек в пазухах нижних пар листьев основной розетки. У этого растения пошли в рост пазушные почки более низких пар листьев и образовали соцветия с розетками листьев в основании, которые в свою очередь ветвились по схеме, представленной выше.

У двулетних видов переход в генеративное возрастное состояние происходит осенью, и тогда же снимается апикальное доминирование. Под зиму растение уходит с зачаточной розеткой вегетативных листьев, апикальным соцветием и двумя или более зачаточными розетками в пазухе верхней пары листьев первого года роста, в благоприятных условиях - у второй пары тоже. На следующий (рис. 2a) год у растения формируется 3-5 розеток листьев и верхушечное соцветие в каждой. Последующее образование в каждой розетке соцветий II порядка происходит так же, как у однолетних особей. Подобная 
схема ветвления характерна для Androsace lactiflora и наблюдалась нами у крупных особей Androsace septentrionales, выросших в особо благоприятных условиях. При приспособлении к более аридными или холодным условиям происходило сокращении продолжительности жизненного цикла до озимых (рис. 2в) и однолетних (рис. 2c) форм. При этом ветвление упрощалось до одной розетки.

Преобразование в многолетние формы, которые живут в холодных условиях высокогорий и высоких широт Арктики, шло двумя разными путями. В первом случае жизненная форма монокарпика во многом сохранялась, как у Androsace albana вида высокогорных пустошей северо-западного Кавказа детально нами исследованного (Любезнова, 2015). У него виргинильная фаза развития может длиться до 7 лет, в зависимости от благоприятности микроусловий в которые попала конкретная особь. В генеративное возрастное состояние растение переходит осенью, заложив новую розетку листьев будущего года. Весной, после разворачивания заложенных вегетативных листьев, у него трогаются в рост все почки у всех листьев в розетке, и число боковых соцветий определяется мощностью растения (рис. 2d). Чем дальше от апикального соцветия расположена пара листьев, тем больше в основании бокового соцветия II порядка формируется пар листьев и меньше - цветков (рис. 2d). Боковые почки у соцветий II порядка в пазухах верхней пары листьев формируются, но их развитие тормозится.

Во втором случае при переходе к многолетнему образу жизни происходила более кардинальная перестройка жизненной формы и смена ритмов развития (Любезнова, 2017). Мы видим частичное ослабление апикального доминирования и удлинение жизни апикальной меристемы, кроме того, растения становятся поликарпичными и после цветения не отмирают. Ветвление происходит ежегодно, но боковые побеги остаются вегетативными, как и апикальная меристема, которая дает две генерации листьев в год: первая гомологична весенней розетке листьев у однолетних форм, вторая - соцветию, где цветки не развиваются, а прилистники становятся нормальными листьями (рис. 2е). Боковые побеги образуются тоже только в определенном месте, там, где должны быть боковые соцветия в пазухах верхней пары листьев (рис. 2е). В зависимости от условий обитания у Androsace capitata менялись число и длина удлиненных междоузлий (Любезнова, 2017). У Androsace villosa и удлиненные междоузлия часто были только у боковых розеток. Соцветие у такой жизненной формы образуется не каждый год, оно только апикальное, и число цветков в нем сильно снижено - обычно не более четырех. В арктических условиях удлиненные междоузлия исчезают (рис. 2f), и формируется растение -подушка, как Douglasia ochotensis. Цветок тоже остается один, причем в северных районах - на Чукотке он сидячий, в более южных формируется цветоножка до 1 см длиной. У F. С. Boucher с соавторами (2012) получилось, что время перехода от двулетних форм к многолетним было вдвое больше, чем перехода от многолетних к подушкам, что оправдано, так как морфологические перестройки при возникновении подушки минимальны.

Отсутствие работы камбия и невозможности многолетнего вторичного утолщения корней и корневищ создает определенные проблемы при поддержании целостности организма. У многолетних форм в удлиненных вегетативных междоузлиях по сравнению с цветоносами наблюдается уменьшение просвета сердцевины, "сползание" пучков и слияние их флоэм (рис. 4), таким образом образуется узкий мелкоклеточный центральный цилиндр в корневище. Кроме того, у него одревесневают три слоя паренхимы под эпидермисом (рис. 4), создавая аналог перидермы. У дерновинных форм происходит полегание и укоренение розеток. Образование новых придаточных корней обеспечивает автономность частей организма и независимость при разрушении старых корневищ. У подушковидных форм должен сохраняться "главный стебель," иначе подушка развалится на части. И выход был найден. Придаточные корни прорастают под одревесневшим эпидермисом с подстилающими слоями в пространстве разрушенной первичной коры стволика подушки и выходят в стороны уже в почве, обеспечивая целостность стволика подушки (рис. 3). В подтверждении этой теории гербарии нами был найден экземпляр Douglasia arctica c разорванным эпидермисом стволика, где видно, что под толстой одревесневшей коричневой корой находится пучок белых корней (рис. 3).

Благодарности. Работа выполнена в рамках темы «Изучение закономерностей морфогенеза и формирования элементов продуктивности под влиянием факторов внешней среды; разработка принизипов морфофизиологической классификачии растений» № AАAА-А16-116021660105-3. 



2

Рис. 1 - схема ветвления однолетнего растения рода Androsace; 2 - Схема преобразования жизненных форм у видов рода Androsace; 3 - фотография стволика Douglasia arctica Hook с разорванным эпидермисом; 4 - поперечный срез удлиненного междоузлия A. capitata. ep - эпидермис, $\mathrm{kc}$ - ксилема, $\mathrm{fl}$-флоэма, c -сердцевина, par -паренхима коры, secr.k -секреторный канал. 


\section{ЛИТЕРАТУРА}

Любезнова Н. В. Особенности морфологического строения генеративных особей Androsace albana Stev. // Фундаментальные и прикладные научные исследования / Сборник статей Междунар. науч.-практ. конф. (Екатеринбург, 5 ноября 2015 г.). - Уфа: Аэтерна, 2015. - Т. 3. - С. 72-76.

Любезнова Н. В. Анатомия, морфология и жизненная форма многолетних Androsace L. //Сборник научных статей по материалам XVI Междунар. науч.-практ. конф.«Проблемы ботаники Южной Сибири и Монголии» (Барнаул, 5 - 8 июня 2017 г.). - Барнаул, Изд-во Алтайского гос. ун-та, 2017. -Т. 16. - С. 131-134.

Boucher F.C., Thuiller W., Roquet C., Douzet R., Aubert S., Alvarez N., Lavergne S. Reconstructing the origins of high-alpine niches and cushion life form in the genus Androsace s.1. (Primulaceae) // Evolution, 2012. - V. 66. - P. 12551268.

Roquet $\boldsymbol{C}$, Boucher $\boldsymbol{F C}$, Thuiller $\boldsymbol{W}$, Lavergne $\boldsymbol{S}$. Replicated radiations of the alpine genus Androsace (Primulaceae) driven by range expansion and convergent key innovations // J. Biogeography, 2013. - V. 40 (10). - P. 1874-1886.

Schneeweiss G. M., Schönswetter P., Kelso S., Niklfeld H. Complex Biogeographic Patterns in Androsace(Primulaceae) and Related Genera: Evidence from Phylogenetic Analyses of Nuclear Internal Transcribed Spacer and Plastid trnL-F Sequences // Systematic Biology, 2004. - V. 53, № 6. - P. 856-876. 